\title{
The Adjudication Function of the Election Supervisory Body (ESB) in Realizing Election Justice
}

\author{
Sahran Raden ${ }^{1}$ \\ Corresponding Email: sahranrdn74@yahoo.com \\ ${ }^{1}$ Faculty of Sharia State Islamic University (SIU) Datokarama Palu, Indonesia
}

\begin{abstract}
ESB's adjudication role and the nature of its presence in Indonesia's electoral justice system are the focus of this research. In a normative juridical approach and analytic descriptive, the researcher examines the legal norms in relevant laws and regulations to determine whether they have been violated. Indonesia's Election Supervisory Board (ESB) was created to ensure free and fair elections that adhere to democratic principles. The election adjudication function is attributable to Law Number 7 of 2017 concerning the ESB as an institution with the authority to resolve electoral process disputes. The existence of the ESB institution has made many positive contributions to the process of democracy development in Indonesia, the large number of violations originating from findings and reports handled by the ESB, is able to provide a deterrent effect for perpetrators of violations of laws and regulations, both election participants and election organizers.
\end{abstract}

Keywords: Election Supervisor, Adjudication, Law, Legislation

Received: July 19, 2021

Revised: August 25, 2021

Accepted: September 4, 2021

\section{Introduction}

The word "democracy" generates a lot of emotion and debate in political discourse (Motala, 2018). Achieving prosperity and justice for all people, and not simply a goal, is the real essence of a democratic society when it comes to social welfare and justice, democracy is just one instrument. There can be no separation in a democracy, where every person has an equal chance to serve their nation, and where authority is limited to prevent abuse by the authorities. The adoption of elections in many nations with time variations is one way to restrict the authority of the government. These occur every 4 years, such as in the Philippines and the U.S. However, others occur every 5 years, such as in Indonesia. A third time cannot be nominated by someone who has been elected 2 (twice) consecutively. This allows other people to participate in the development of the country, either by nominating regional leaders or national leaders (Satriawan, 2019).

There are essential components of a democracy, including elections and political parties This means that any study of election law must also include a consideration of how representative institutions are composed and positioned since general elections are conducted in order to fill those positions. Voting is an essential part of the democratic process in every nation (Lathif et al., 2020). Despite the fact that democracy is not the same thing as general elections, elections are one of the most important aspects of democracy that must be conducted democratically. As a result, in most democracies, elections are held to elect public representatives in the legislative and executive branches, both at the center and in the regions (Aras Firdaus, 2020). Example: The presidential election between Hillary Clinton and Donald Trump in 2016 (Hasen, 2020). Besides the need of a law, which must precede the exercise of a power, every action of the 
government must be incorporated and carried out in the form of a law and its principles (Cichelero et al., 2018).

According to Indonesia's progressive legal norm system (stufentheory), a product of legislation may not clash with higher laws and regulations (Anggraini et al., 2020). It is outlined in Article $22 \mathrm{E}$ of Chap. VIIIB of the 1945 Constitution. Yet another focuses on the importance of fairness, honesty, and secrecy in the conduct of elections. These principles must be implemented by an electoral commission. They're not enough. In addition, an impartial electoral body must be in charge of overseeing elections. A nationwide, permanent and independent general election commission is required under Article 22E paragraph 5 of the 1945 Constitution. The establishment of an independent election commission is necessary in order for the general election commission to operate properly and for all election commission decisions to be free from influence from any party (Huda, 2019). There is a new law in place, the Indonesian Law No. 3 of 1999 on General Elections, which revokes the previous Indonesian Law No. 1 of 1985, which amended the 1969 law, Law No. 15 of 1969, concerning the general election of members of the Consultative Body/Representatives, People's as amended by Laws Nos. In addition, the Third Amendment to the 1945 Constitution of the Republic of Indonesia includes rules on election administration (Tahe et al., 2021).

Indonesian elections are likely to be fraught with problems. As a result, it's essential to prepare for every general election. Infrastructural and organizational deficiencies remain in the election administration. On the basis of the results of the general election, each institution has different degrees of power (Siboy, 2021). Government continues to tighten regulations to ensure that elections are conducted according to popular sovereignty principles that are carried out directly, publicly, freely, confidentially, honestly and fairly within Indonesia's unitary state, based on Pancasila and the Constitution of the Republic of Indonesia of 1945 (Kusuma et al., 2019). The Election Supervisory Agency has experienced significant changes as a result of the adoption of Law No. 12 from 2003. It is because of this legislation that a special entity for election oversight, consisting of the Election Supervisory Committee, is established, regardless of how the GEC is structured.

Election Supervisory Committees for the Province, the Regency/Municipal, and the District Law No. 7 of 2017 on Election Organizers also created the Election Supervision Body, which strengthened the election supervision institution (Nur Aisyah Fitri Boru Nainggolan, 2021). When it comes to election disputes, an electoral dispute resolution organization is in responsibility of ensuring that the process is free and fair (see Article 93 letter b of the Election Law). As of May 20, 2019, the ESB has processed 458 criminal cases out of 8,512 findings and complaints. There are now 111 criminal judgements in the United States. Out of them, 103 are invalid and 8 have been appealed (Haryanti, 2020).

By monitoring election organizers across the whole area of Indonesia's Unitary State, the ESB is responsible for overseeing elections. The ESB is permanent. For its part, the ESB is responsible for overseeing all aspects of the election process, including preparation and execution. This is done to provide effective supervision, since the supervisory agency, the ESB, must be separated from the institution it monitors. Since the General Election Organizers Act of 2007, the ESB and GEC no longer operate in tandem (Devi, 2019).

This is a breath of fresh air, as it encourages clean elections and Regional Head Elections (RHE) that are free of fraud, particularly the process of violations done by competing candidate pairs and their success teams in winning the election/RHE. This ad hoc institution was initially established in 1982 as part of the 1982 general election process (Ariffin, 2019). The ESB and the election administration may supervise suspected criminal actions committed by all 
components of the election administration that are addressed in general courts. Accordingly, ESB resolves administrative disputes between participants and the General Election Commission. Any accusations of election and regional code-of-ethics breaches that are made will be sent to the Election Organizing Honorary Council (EOHC). When it comes down to it, the constitutional court will have the last say. A special judiciary body must be created before elections may be conducted by the constitutional court, which is doing so at the present time (Hidayat et al., 2019). Because of its decision to abolish the Constitutional Court's power to settle disputes over election results in Decision Number 97/PUU-XI/2013, the law's mandate to create a "special judicial body" has given rise to fresh optimism (Firmanto et al., 2021).

\section{Methods}

This type of research uses qualitative research (Samad \& Kusuma, 2020), examination of legislation and regulations relating to the responsibilities and powers of the Election Supervisory Body (ESB). The literature research technique is used to gather data (Mutiarasari $\&$ Herawati, 2020). As a result of data verification to enhance the quality of the information gathered and then deleting data that is considered irrelevant (Hasbullah, Muhammad Ahsan Samad, 2021). Legal issues may be solved based on the findings of reviewing the legal legislative ratio. For this research, the conceptual method departs from the legal science's ideas and doctrines, particularly those that have evolved in relation to the ESB's responsibilities, obligations, and powers in administering fair elections. These concepts were learned from legal texts. Indonesia's Constitution is used as a basis for this strategy, as well as Law No. 7 of 2017 covering elections and election-related laws (Sabrina \& Ristawati, 2021).

\section{Results and Discussion}

\section{The Existence of ESB in Election Dynamics in Indonesia}

People's sovereignty will be ensured by revising and updating the 1945 Constitution. In line with Article 1 Paragraph 2 of the 1945 Constitution, the people have sovereignty, which they exercise according to the Constitution. A democracy's sovereignty resides in its people, who implement it in accordance with the Constitution. There is a legal politics for constitutional amendments, for example, that aims to enhance the people's sovereignty system. In accordance with the 1945 Constitution, Indonesia has either a direct or representative democracy. It is through elections that a democratic system is established.

According to Article 27 paragraph 1 of the 1945 Constitution, the right to vote cannot be revoked due of procedural restrictions, proving the constitution represents the people's sovereignty. elections under the 1945 Constitution Amendment of the Republic of Indonesia are intended to provide strong legal grounds for achieving

popular sovereignty. In Indonesia, General Elections are regulated by Law No. 7 of 2017, which aims to delegate people's sovereignty and implement a democratic political system. Article 1 point 1 of Law No. 7 of 2017 defines "election" as a direct, public, and free means of exercising people's sovereignty to elect members of the People Representative Council, Regional Representatives Council, President and Vice President, and to elect members of regional people's representative councils.

Even if a policy plan is excellent and well-thought-out, it will not be successful if its implementation unit is not involved and determined (Pasinringi et al., 2020). To promote smooth election implementation, the ESB has been designated as an official entity to supervise the different phases of the election. The presence of election supervision institutions in general, on the other hand, is proving to be less than ideal when it comes to fulfilling their 
responsibilities. the Election Supervisory Board (ESB) is now authorized to carry out electoral justice functions in accordance with Law No. 7 of 2017 concerning General Elections. The ESB is no longer just a supervision body, but is also authorized to act as an electoral judiciary institution, or at least is given the authority to carry out electoral justice functions in accordance with the trial model. to the public. Law number 7, passed in July of 2017, gives ESB tremendous power. It may act as a supervisor and an executor for judges who determine cases. Due to the complexity of Indonesian elections, it is anticipated that the ESB would demonstrate its vital function and existence in ensuring the integrity of elections for Indonesia's development.

On the basis of Law Number 7 of 2017 concerning Elections, the ESB will exist in the next elections in 2019. For Indonesia's elections to be free and fair, the ESB's role is critical. By having adjudication power and an institutional framework down to the polling station supervisory level, the 2019 election supervisory structure was enhanced. A primary goal of the ESB's election supervision is to prevent electoral fraud. The adjudication authority, on the other hand, becomes a tool to ensure a fair election when there is a violation. With regard to election oversight, this means that the ESB's power to investigate and resolve election issues via adjudication will be used to avoid possible election breaches. A type of ESB monitoring is anticipatory on the one hand, and repressive on the other. According to the election legislation, the ESB's institutional architecture mandates that prevention, monitoring, and prosecution are merged into one coherent function. Law 7 of 2017 on elections provides a normative framework for achieving this goal.

Elections have been made more honest and fair thanks to the ESB. ESB's role as an election supervisor is critical to achieving a democratic system that operates honestly, fairly, and with dignity and integrity." Since its inception, the ESB institution in Indonesia has made a significant contribution to the democratic development process. The large number of violations that result from findings and reports handled by the board deter violators of laws and regulations, as well as those who organize and participate in elections.

To ensure that it has the authority to carry out election monitoring and to take action against election breaches, ESB reinforced its institutional hierarchy with the passage of Law 7 of 2017. According to the ESB's performance in the 2019 parliamentary elections, this is a departure from prior elections. First, the ESB has a strong institutional framework that extends all the way down to the polling station supervisor, thus the ESB is a genuine entity when it comes to election monitoring. Another reason is that election disputes cannot be arbitrated by any party since the ESB is allowed by law to act as an adjudication or decision-making body. Because of the ESB's role in Indonesia's election dynamics, elections may be conducted with dignity and in line with the people's sovereignty.

\section{Legal Aspects of ESB Adjudication Authority in Elections}

The ESB is an election management organization with the power to oversee elections as well as adjudicate elections, according to its charter. In order to ensure electoral fairness, Law 7 of 2017 on General Elections grants this adjudication power. To avoid and resolve election disputes, the ESB is mandated by Law Number 7 of 2017 on General Elections. In taking action against electoral process disputes, the ESB is tasked with: (a) receiving applications for dispute resolution in the election process; (b) verify formally and materially the application for dispute resolution in the election process; (c) mediate between disputing parties; (d) conduct the adjudication process for electoral process disputes; and (e) decide on the dispute resolution of the electoral process. 
These sections make clear that ESB's jurisdiction over election issues is exercised at various levels, including accepting applications, verifying them formally and materially, facilitating mediation and adjudication processes, and adjudicating disputes over election processes. In addition, the ESB was given the power to receive, investigate, arbitrate or judge election disputes, as well as to modify judgments and recommendations made by the Provincial ESB and Regency/Municipal ESB if they are in violation of the law. The authority for dispute resolution of the election process carried out by the ESB is related to the issuance of the decision of the General Elections Commission (GEC) as stipulated in Article 5 paragraph (1) of the ESB regarding the procedures for resolving disputes over the election process that "ESB has the authority to resolve disputes over the election process caused by a decision GEC". Thus the relative competence of the electoral process dispute resolution authority exercised by the ESB is only to the decisions issued by the GEC.

The ESB has a hierarchical structure, with the Provincial ESB having the power to settle complaints regarding the election process. Law No. 7, 2017 on General Elections, states that "Provincial ESBs are charged with the prevention and resolution of election process issues in provincial regions." In taking action against election process disputes, the Provincial ESB is tasked with: a) receiving requests to resolve election disputes in the province; b) formal and material verification of requests to resolve election disputes in the province, c) mediating disputes between disputing parties in the province, $\mathrm{d}$ ) adjudication if mediation hasn't resolved the dispute and e) decide on the dispute resolution of the election process in the province.

They further stressed how the Provincial ESB has jurisdiction over election disputes in the province and has the power to accept, analyze or arbitrate or adjudicate any disputes that may arise in this process. When it comes to the Election process, the Provincial ESB is authorized to settle disputes arising from decisions made by the Provincial GEC, as stated in Article 5 paragraph (2) of Perbawaslu about Procedures for the Settlement of Election Process Disputes. Thus, the relative competence of the electoral process dispute resolution authority carried out by the Provincial ESB is only to the decisions issued by the Provincial GEC. Regency/Municipal ESB as stipulated in the Election Law stipulates that "Regency/City ESB has the task of preventing and taking action in the district/city territory against electoral process disputes".

ESBs in Regency/Municipal areas are responsible for the following: (a) receiving applications for dispute resolution of the election process in the Regency/Municipal territory; (b) verifying the application for dispute resolution in the district/city territory; (c) mediating between the parties in dispute in the district/city territory; (d) if mediation has not yet addressed the issue over the election process, adjudicate the matter in the district/city area; and (e) determine how to settle the dispute over the election process in the regency/city territory. It was also emphasized that "Regency/Municipal ESB has the authority to receive, examine, mediate or adjudicate, and decide on the settlement of electoral process disputes in the regencies/municipalities". The authority for dispute resolution of the Election process carried out by Regency/Municipal Bawaslu is the issuance of Provincial GEC decisions as stipulated in Article 5 paragraph (3) of the GEC concerning Procedures for Settlement of Election Process Disputes that "Provincial ESB has the authority to settle disputes over the Election process caused by a decision Regency/City GEC".

Thus, the relative competence of the authority for dispute resolution in the election process carried out by the Regency/City ESB is only to the decisions issued by the Regency/City GEC. Furthermore, in Article 5 of the GEC concerning Procedures for Settlement of Election Process Disputes, it is stipulated that: "(1) the ESB has the authority to settle disputes over the Election 
process resulting from the GEC's decision; (2) The Provincial ESB has the authority to settle disputes over the Election process caused by the decision of the Provincial GEC; (3) Regency/Municipal ESB has the authority to settle disputes over the Election process caused by the Regency/Municipal GEC Decree; (4) These committees may help resolve issues that arise between Election Participants regarding the election process as part of the execution of the mission of the Regency/Municipal ESB”.

The disputed GEC decision is the determination of the permanent list of candidates for members of the People's Representative Council (PRC), Regional People's Representative Council (RPRC), Province and Regency/City RPRC. The decision is considered not in accordance with the procedures in the stage of determining the permanent candidate. The process for dispute requests is carried out according to procedures, from mediation to adjudication which ultimately results in a decision. The decision of the ESB is final and binding in accordance with the Election Law.

The dispute resolution of the election process, which is continued at the adjudication stage, is first formed by an adjudication assembly. An Adjudication Council will be formed by the ESB, Provincial ESB, or Regency/Municipal ESB based on the number of applications for dispute resolution cases in the election process. There are at least three (3) ESB members on the adjudication panel, with one (1) ESB member serving as the trial assembly's chairman, and two (2) ESB members serving as members of the trial assembly. At least three (3) Provincial ESB members form a trial assembly, with one (1) Provincial ESB member serving as the trial assembly's chairman, and two (2) other Provincial ESB members serving as trial assembly members. At least three Regency/City ESB members form a trial assembly, with one Regency/City ESB member serving as chairman and two Regency/City ESB members serving as tribunal members.

\section{Election Justice}

Legitimate nations have traditionally relied on the idea of administrative justice to resolve conflicts (Retnaningsih et al., 2021). In contrast to the legal justice paradigm, electoral justice takes a different approach. It was argued by L.J. Van Apeldoorn that justice should not be equated with equality. Because each situation must be evaluated individually, what is fair for one person may not be so for another. To govern peaceful existence, a fair regulation is needed. A just regulation is one that strikes a balance between protected interests, ensuring that everyone who is a part of it receives the maximum benefit. As Satjipto Rahardjo puts it, "to construct the idea of justice how to build justice based on the principles of balance on equal rights and responsibilities". Also important to examine is how well the legal system works by establishing and enforcing legal rules, then imposing penalties to community members in accordance with those regulations, i.e. what acts may and cannot be carried out. It is necessary, however, to promulgate regulations that govern the processes and norms for executing these procedural regulations.

Electoral justice ensures that elections may be conducted in an honest and fair manner. In order to ensure the efficiency of elections, the electoral justice system is essential. Democracy can only be achieved via elections that are fair. The electoral justice system is also a mechanism that ensures that election law enforcement is carried out with legal certainty. Siregar (2020) believes that democratic elections with honesty and dignity are essential to a democracy. Electoral involvement is regarded as the most tangible expression of people's sovereignty and engagement in state governance. Wahlen play an important role in linking infrastructure and political superstructure. As long as the election is conducted in a fair and honest way, the state is regarded to be effectively executing democracy. 
It's possible to observe the electoral justice system in the election's legal structure. Any election-related problems may be dealt with within a legal framework. We can ensure fairness in the administration of all administrative, criminal, and ethical electoral infractions procedures. As a result of the electoral justice system, conflicts between participants in the election may be addressed on time. According to Oliver Joseph and Frank McLoughlin (2019), elections offer what is known as an electoral justice system to guarantee that elections may operate properly and fairly. For elections to be efficient and fair, the electoral justice system is essential. Prevention and dispute resolution procedures are included as part of the electoral justice system.

Every action and decision made in the election process must comply with current legal frameworks in this system, according to the IDEA, and there must be legal mechanisms to redress any breaches of a voter's right. These activities have been controlled and methods have been given for addressing legal problems. As a result, the legislative foundation for the electoral justice system has been established. Although the legislative framework has been created, it does not guarantee that the elections will be conducted fairly after it has been implemented. Confirming that the electoral process is fair requires examining how the election organizers have implemented their electoral justice system.

There must be an honest and fair system of general elections for democracy to flourish (free and fair elections). On the other hand, if there are laws in place that regulate the election process, it will be possible to ensure that elections are free of fear or intimidation or violence. By doing so, election observers and people in general will be safeguarded from corruption, fraud and other deceptive activities that may influence the election outcomes. Electoral law and regulation enforcement officers are required because elections must be performed in conformity with the electoral rules and regulations set out by the federal government.

\section{ESB Adjudication Function in Realizing Election Justice}

The ESB is mandated by law to investigate and prosecute breaches of electoral administration and to resolve disputes about the election process. For the purposes of resolving disputes arising from the election process as a consequence of GEC decisions, Provincial GEC decisions, and Regency/City GEC decisions, ESB accepts petitions for dispute resolution. It is the responsibility of the ESB to investigate and take action against breaches of an electoral administrative character. Three (three) working days after the ESB decision is read out, the GEC, Provincial GEC, and the Regency/City GEC must take action.

To prosecute and resolve election process issues, the ESB is responsible for accepting applications, confirming officially and physically, meditating between opposing parties as well as adjudicating and determining the settlement of electoral process disputes. It is important to note that ESB decisions regarding the resolution of electoral process disputes are final and binding, except for decisions on electoral process disputes related to the verification of Election Contesting Political Parties, determination of candidates for PRC and Regional Representative Council (RRC) members, as well as determination of Candidate Lists. As stipulated in the election law, for legal considerations, the ESB decision must fulfill the elements of the authority of the ESB, Provincial ESB, or Regency/Municipal ESB, legal position, grace period for submitting an application, principal of the request and conclusion. This means that the legal considerations of the ESB's decision are bound by the mechanism, the applicable legal procedures as regulated in the ESB regulations. The consideration of the ESB legal decision in the adjudication trial panel is made in accordance with the stages of the judge in deciding a case in court. The consideration of the ESB's legal decision is obliged to confirm or see to justify the existence or absence of an event that is submitted to it. 
The ESB is required to assess whether a case needs evidence before accepting it. It is essential that the ESB's legal judgment be based on legal facts before it can be considered. If an incident occurs during the election period, ESB legal judgments must adhere to a legislative rule. Legal values of facts may be explored by ESB. It can be followed and understood. As a result, the examination of the ESB's legal judgment is a natural step in the process of ensuring electoral fairness.

As part of an attempt to enforce election law and election fairness, the ESB has been given the power to adjudicate election breaches and electoral process issues. To maintain democratic legislation in Indonesia, Indonesians want the ESB to enforce election fairness. Protecting people' rights in politics is a function of enforcing electoral justice So that there is no impression or perspective of different parties where the ESB conducts bribery and manipulative corrupt activities, the ESB's judgment in settling election disputes must be fair and truthful.

The election legislation gives the ESB responsibilities and powers to address administrative breaches and electoral process issues as a bulwark for the community in its quest for justice The ESB is needed to enhance both the administrative system and the judicial system as an institution that pursues electoral justice. As an example, the legal reasoning processes of the decision maker may be found in the form of an ESB decision's language Justice, benefits and legal clarity are anticipated to be taken into consideration in ESB's legal judgments when it comes to addressing administrative breaches and electoral dispute settlement.

The nature of the decision issued by the ESB must be interpreted as a decision issued by a quasi-judicial or quasi-judicial institution whose position is the same as that of the judges in court. According to Mertokusumo, (2014) states that the ideal judge's decision is if it contains elements of Gerechtigkeit (justice), Zweckmassigkeit (benefit), and Rechtssicherheit (legal certainty) proportionally. A judge's decision must be fair, but it must also be beneficial for the person concerned and the community, and guaranteed legal certainty. A decision is expected to give satisfaction to all parties in a case, by providing legal reasons or considerations in accordance with the values of truth and justice. A better understanding of emotional intelligence will be needed when judges interact with participants in varying degrees of emotion and compassion, investigate therapeutic justice therapies, or pursue procedural justice techniques (Sourdin \& Cornes, 2018). As Rifai (2011) points out, the court plays a crucial role in establishing the content and strength of positive legal norms. Judicial power is exercised by judges when they investigate and assess human behavior and the context of their involvement. When problems or disagreements arise, they use the law as a standard of reference. We anticipate that judicial institutions would be transparent, accountable and mindful of the quality of their decisions.

Having a competent judiciary is a sign of a democratic election system in every democratic nation. In the principles of electoral conflicts, there is a mechanism for enforcing and resolving disputes. It is essential that the election dispute resolution system be able to protect the political rights of people, including their participation in government, in order to achieve electoral fairness. For example, in the United States, there is a mechanism for ensuring that elections are free, fair and honest that is known as electoral justice, where the instrument is used to enforce the law.

Assuring the validity of democracy and election process requires a well-defined framework for electoral fairness. It's important to remember that electoral fairness isn't only about executing the law; it's also about planning and administering the whole election process. Aspects such as electoral fairness may influence the conduct of participants in the process. System and 
procedures vary throughout the globe since the electoral justice system is heavily affected by socio-cultural circumstances, historical and political contexts.

One of the ways the concept of justice is enforced is through the judge in court, according to Joseph, Oliver, and Frank McLoughlin (2019). To decide whether an incident or mistake has been proved, a judge must make a judgment based on his or her moral integrity as well as on the availability of evidence according to the law. When a judge makes a judgment, he or she must take into account a number of factors, including the nature of the case, the degree of action taken, and what the offender did to the interests of the parties. As well as that, it's an expression of the judge's mandate to the country, which has made the judiciary one of the authorities to communicate his will (Gersdorf \& Pilich, 2020). Before making a decision, the judge must ask himself, is he honest in making this decision, or has the decision he made correct, will be able to resolve a dispute, or is this decision fair or how far the benefits of the decision handed down by a judge are for the parties. in the case or for society in general.

According to different election rules, the ESB's role is primarily to oversee the conduct of elections. The Election Law establishes the ESB as an organization with the primary responsibility of overseeing the conduct of elections and municipal elections in Indonesia, according to the law's provisions. This is reasonable, since an election without a process and an atmosphere of open and independent monitoring would turn into a contestation field replete with fraud and deceit. The elections will be handled in a dishonest and unfair way. To have a democratic election needs a monitoring agency that is independent, autonomous, and independent. There was a need to strengthen the democratic pillars, reduce the incidence of election fraud, and use elections as a way of exercising people's sovereignty to create a democratic government.

\section{Conclusion}

Because of the ESB's adjudicatory powers, legal principles such as clarity, fairness, and legal expediency may be achieved. By enforcing the law in an effective and efficient manner, the law's intended goal may be achieved Justice, legal clarity, and social benefits are the goals of law enforcement. Concrete law enforcement is putting positive law into reality and enforcing it to the fullest extent possible Given that the formal law establishes procedural rules, delivering justice involves making a concrete legal decision while simultaneously ensuring and preserving the compliance of material law. The purpose of the ESB in Indonesian elections is to ensure free and fair elections in order to uphold the ideals of honest and democratic elections in Indonesia. Candidates and political parties have the ability to violate election laws at every step of the election process. As a result, the electoral law framework offers an institutional architecture for the ESB as an election organizer that can effectively and efficiently enforce electoral fairness. Indonesian electoral justice may be achieved via the ESB's adjudication role, which is a result of Law Number 7 of 2017 addressing elections.

\section{References}

Anggraini, R. A. R., Ekatjahjana, W., Rato, D., \& Harianto, A. (2020). Politic of Law on Judicial Review of Local Government Regulation in Indonesia. Journal of Law, Policy and Globalization, 98(12), 140-151. https://doi.org/10.7176/jlpg/98-20

Aras Firdaus. (2020). Money Politics Dalam Pemilihan Umum Oleh Badan Pengawasan Pemilihan Umum: Pengawasan Tindak Pidana Pemilu. Justiqa, 2(1), 1689-1699.

Ariffin, M. (2019). Peran Badan Pengawas Pemilu (Bawaslu) Kabupaten Polewali Mandar Dalam Pengawasan Pelanggaran Pemilu Pada Pemilihan Kepala Daerah (Pilkada) 
Serentak Tahun 2018. Journal Peqguruang: Conference Series, 1(2). https://doi.org/10.35329/jp.v1i2.558

Cichelero, C. A., Ferri, C., \& Nunes, E. B. (2018). From an idealized separation of powers to its practical problems in the rule of law. Revista de Investigacoes Constitucionais, 5(1), 15-40. https://doi.org/10.5380/rinc.v5i1.55929

Devi, P. G. (2019). Sengketa Verifikasi Partai Politik pada Badan Pengawas Pemilihan Umum. Jurist-Diction Law Journal, 2(5), 1787-1798. https://doi.org/10.20473/jd.v2i5.15243

Firmanto, T., Fadli, M., Safaat, M. A., \& Istislam, I. (2021). The Dynamics of Organizing Institutions for the Resolution of Election Conflicts in Indonesia During 2005-2020 Period. Proceedings of the 2nd Annual Conference on Education and Social Science (ACCESS 2020), 556(Access 2020), 339-344. https://doi.org/10.2991/assehr.k.210525.103

Gersdorf, M., \& Pilich, M. (2020). Judges and Representatives of the People: A Polish Perspective. European Constitutional Law Review, 16(3), 345-378. https://doi.org/10.1017/S1574019620000206

Haryanti, D. (2020). The Reconstruction of Membership Elements of the Election Supervisory Board in Realizing Higher Quality Elections. UNIFIKASI: Jurnal Ilmu Hukum, 07, 174-183. https://doi.org/10.25134/unifikasi.v7i2.2767

Hasbullah, Muhammad Ahsan Samad, D. (2021). The Regional Impact Of Land-use Change: Social, Economic and Political Environment in Central Sulawesi Indonesia. Technium Social Sciences Journal, 19, 46-54.

Hasen, R. (2020). Deep Fakes, Bots, and Siloed Justices: American Election Law in a "PostTruth" World. Saint Louis University Law Journal, 64(4), 3.

Hidayat, A. S., Helmi, M. I., \& Alam, F. S. (2019). Implementation of the Contante Justitie Principle of Justice in Local Leaders Election and General Election in Indonesia. International Journal of Engineering and Advanced Technology, 9(2), 2699-2703. https://doi.org/10.35940/ijeat.b2906.129219

Huda, U. N. (2019). the Position and Authority of the Election Supervisory Board in Indonesian Constitutional System. UNIFIKASI : Jurnal Ilmu Hukum, 6(1), 71. https://doi.org/10.25134/unifikasi.v6i1.1807

Kusuma, L. S. T., Zulhadi, Z., Junaidi, J., \& Subandi, A. (2019). Peran Badan Pengawas Pemilihan Umum dalam penegakan hukum Pemilu (studi penanganan pelanggaran Pemilu pada Sentra Gakkumdu Provinsi Nusa Tenggara Barat). Jurnal Ulul Albab, 23(2), 110-116. http://journal.ummat.ac.id/index.php/JUA/article/view/1733/1291

Lathif, N., Insan, I. H., \& Wijaya, M. M. (2020). Perspective on Settlement of General Election Disputes Through Mediation, Adjudication and Legal Efforts : Settlement of State Administrative Judicial Disputes. International Journal of Multicultural and Multireligious Understanding, 7(5), 650-661.

Motala, Z. (2018). Brexit, the Election of Donald Trump and Activism in South Africa, Lessons for Democracy: The Contribution of Justice Sandile Ngcobo. Southern African Public Law, 32(1\&2), 1-36.

Mutiarasari, N. N., \& Herawati, R. (2020). Supervision of Bawaslu Pemalang Regency in the 2020 Regional Head Election. Law Reform, 16(2), 264-275. 
Nur Aisyah Fitri Boru Nainggolan, M. (2021). Peran Badan Pengawas Pemilu Dalam Menyelesaikan Sengketa Pemilu Berdasarkan Undang-undang Nomor 7 Tahun 2017 (Studi Pada Bawaslu Kabupaten Deli Serdang) Nur. Jurnal Hukum Dan Kemasyarakatan Al-Hikmah, 2(1), 160-170 